\title{
PREPARATION AND REDUCTIVE ELIMINATION OF DIGERMYLPLATINUM COMPLEXES
}

\author{
Kunio Mochida, * Tohru Wada, Wakako Hatanaka,Yuriko Nishiyama, \\ Michiko Suzuki, and Masato Nanjo
}

Department of Chemistry, Faculty of Science, Gakushuin University, 1-5-1 Mejiro, Toshima-ku, Tokyo 1711-8588, Japan

\begin{abstract}
R}_{3} \mathrm{Ge}\right)_{2} \mathrm{Pt}\left(\mathrm{PMe}_{2} \mathrm{Ph}\right)_{2}$ complexes as key intermediates of bis-germylation of alkynes have been prepared, and their structures have been established by spectroscopic methods and $\mathrm{X}$-ray crystallography. The cis isomers afford digermanes, $\left(\mathrm{R}_{3} \mathrm{Ge}\right)_{2}$ as reductive elimination products in good yields. In contrast, the trans isomers lead to monogermanes.
\end{abstract}

\section{Introduction}

A transition metal-catalyzed addition of group 14-element compounds to unsaturated organic substrates is a useful fundamental process in group-14 element chemistry. The addition of $\mathrm{Si}$-Si bonds to $\mathrm{C}-\mathrm{C}$ triple and double bonds, i.e., bis-silylation, has attracted considerable current interest in the synthesis of fundamental molecules and in application to selective organic synthesis [1-8]. For bis-silylation method and of considerable studies on reaction mechanisms, there have been few reports on bis-germylation reactions [9-11]. We report on the synthesis, characterization, and reactivities of digermylplatinum complexes that assumed as key intermediates in these platinum-catalyzed processes.

\section{Results and Discussion}

We set out to prepare model compounds of the intermediate digermylplatinum complexes stabilized by tertiary phophine ligands. Using dimethylphenylphosphine ligand as supporting ligands, we have been able to prepare digermylplatinum complexes, $\left(\mathrm{Me}_{2} \mathrm{PhGe}\right)_{2} \mathrm{Pt}\left(\mathrm{PMe}_{2} \mathrm{Ph}\right)_{2} \quad$ (1), $\left(\mathrm{MePh}_{2} \mathrm{Ge}\right)_{2} \mathrm{Pt}\left(\mathrm{PMe} \mathrm{Ph}_{2}\right.$ (2), and $\left(\mathrm{Ph}_{3} \mathrm{Ge}\right)_{3} \mathrm{Pt}\left(\mathrm{PMe} \mathrm{Ph}_{2}\right)_{2}(3)$. The treatment of $c l s-\mathrm{PtCl}_{2}\left(\mathrm{PMe}_{2} \mathrm{Ph}\right)_{2}$ with two equiv of $\mathrm{Me}_{2} \mathrm{PhGeI} \mathrm{i}$, prepared from the corresponding germyl chloride with lithium metal, in THF at room temperature for $12 \mathrm{~h}$ afforded yellow crystals with a composition of $\left(\mathrm{Me}_{2} \mathrm{PhGe}\right)_{2} \mathrm{Pt}\left(\mathrm{PMe}_{2} \mathrm{Ph}\right)_{2}(1)$. NMR examination of $\mathrm{a} \mathrm{C}_{6} \mathrm{D}_{6}$ solution of the yellow crystals showed a single cis-isomer: ${ }^{1} \mathrm{H} N \mathrm{NM}\left(\mathrm{C}_{6} \mathrm{D}_{6}\right) \delta 0.73\left(\mathrm{~d},{ }^{2} J_{\mathrm{H} \mathrm{P}}=8.1 \mathrm{~Hz},{ }^{3} J_{\mathrm{H}-\mathrm{P}}=29.9 \mathrm{~Hz}\right.$, $\left.\mathrm{PCH}_{3}\right), 1.05\left(\mathrm{~s},{ }^{3} J_{\mathrm{H} \cdot \mathrm{Pt}}=17.6 \mathrm{~Hz}\right),{ }^{31} \mathrm{P} \mathrm{NMR}\left(\mathrm{C}_{6} \mathrm{D}_{6}\right) \delta-10.1\left(\mathrm{~s},{ }^{1} J_{\mathrm{pr}-\mathrm{P}}=2007 \mathrm{~Hz}\right)$. Complex cis-1 in $\mathrm{C}_{6} \mathrm{D}_{6}$ was stable and did not isomerize to the trans-isomer, even at $70^{\circ} \mathrm{C}$. The complex cis $\cdot \mathrm{PtCl}_{2}\left(\mathrm{PMe}_{2} \mathrm{Ph}\right)_{2}$ reacted with two equiv of $\mathrm{MePh}_{2} \mathrm{GeLi}$, prepared from the corresponding germyl chloride with lithium metal, in THF at room temperature for $12 \mathrm{~h}$ to give yellow crystals with a composition of $\left(\mathrm{MePh}_{2} \mathrm{Ge}\right)_{2} \mathrm{Pt}\left(\mathrm{PMe}_{2} \mathrm{Ph}\right)_{2}(2)$. A NMR examination of the $\mathrm{C}_{6} \mathrm{D}_{6}$ solution of the yellow crystals 2 showed the presence of cis and trans isomers of 2 in an approximately 60:40 ratio. The ${ }^{1} \mathrm{H}$ NMR of complex cis-2 displayed the two methyl signals of the $\mathrm{PhMe} 2 \mathrm{Ph}$ ligands at $0.70 \mathrm{ppm}$ (deformed $\mathrm{q}^{2}{ }^{2} J_{\mathrm{H} \mathrm{P}}=8.2 \mathrm{~Hz},{ }^{3} J_{\mathrm{HP}}=20.8 \mathrm{~Hz}$ ) and the platinum bound methyldiphenylgermyl groups at $1.05 \mathrm{ppm}\left(\mathrm{s},{ }^{3} \mathrm{~J}_{\mathrm{H} \mathrm{Pt}}=18.6 \mathrm{~Hz}\right)$. The ${ }^{31} \mathrm{P} N \mathrm{NR}$ showed a singlet signal with satelltes at $-10.99 \mathrm{ppm}\left({ }^{1} J_{\mathrm{P}-\mathrm{P}}=2049 \mathrm{~Hz}\right)$. The trans-2 isomer exhibited ${ }^{1} \mathrm{H}$ NMR spectrum of the germanium-bound methyl groups at $1.20\left(\mathrm{vt},{ }^{2} J_{\mathrm{H} \cdot \mathrm{P}}=6.0 \mathrm{~Hz},{ }^{3} J_{\mathrm{H} \cdot \mathrm{P}}=30.8 \mathrm{~Hz}\right)$ and the ${ }^{31} \mathrm{P}$ NMR showed a single at $-10.63 \mathrm{ppm}$ with satellites $\left({ }^{1} J_{\mathrm{P} \cdot \mathrm{P}}=2731 \mathrm{~Hz}\right)$. The smaller ${ }^{1} J_{\mathrm{P}-\mathrm{p}}$ value in cis-2 is consistent with the the larger trans influenece of the germanium ligand situated at the position trans to the phosphine ligand. From the cis and trans mixture, cis-2 could be isolated as yellow crystals by recrystallization from a 5:1 mixture of hexane and benzene at room temperature for 3-5 days.

Complex cis- $\mathrm{PtCl}_{2}\left(\mathrm{PMe}_{2} \mathrm{Ph}\right)_{2}$ reacted with two equiv of $\mathrm{Ph}_{3} \mathrm{GeL} i$, prepared from $\mathrm{Ph}_{3} \mathrm{GeCl}$ and lithium metal, in THF under similar conditions to give yellow crystals of only one species $\left(\mathrm{Ph}_{3} \mathrm{Ge}\right)_{2} \mathrm{Pt}\left(\mathrm{PMe} \mathrm{P}_{2} \mathrm{Ph}\right)_{2}(3)$ having a trans geometry: ${ }^{1} \mathrm{H} N \mathrm{NM}\left(\mathrm{C}_{6} \mathrm{D}_{6}\right) \delta 1.24\left(\mathrm{vt},{ }^{2} J_{\mathrm{H} \cdot \mathrm{P}}=29.3 \mathrm{~Hz},{ }^{3} J_{\mathrm{H} \cdot \mathrm{P}}=6.6 \mathrm{~Hz}, \mathrm{PCH}_{3}\right),{ }^{31} \mathrm{P} \mathrm{NMR}\left(\mathrm{C}_{6} \mathrm{D}_{6}\right)$ $\delta-11.0\left(\mathrm{~s},{ }^{1} J_{\mathrm{P}-\mathrm{P}}=2616 \mathrm{~Hz}\right)$. The complex trans- 3 in $\mathrm{C}_{6} \mathrm{D}_{6}$ was stable and did not isomerize to the $\mathrm{cis}$ isomer, even at $70^{\circ} \mathrm{C}$. Thus, the stable geometry for $\left(\mathrm{R}_{3} \mathrm{Ge}\right)_{2} \mathrm{Pt}\left(\mathrm{PMe} \mathrm{Ph}_{2}\right)_{2}$ complexes varies dependent on the number of phenyl groups on the germanium atom. The structure of cis-1, cis-2, and trans-3 were established by NMR, IR, and X-ray analysis. Although crystallized 2 has a cis geometry, the dissolution of cis- 2 in benzene caused a gradual isomerization to give a cis-trans equilibrium mixture. 
$\delta 1.05 \mathrm{ppm}$

(s with two satellites) $\delta 0.48 \mathrm{ppm}$

(s with two satellites)

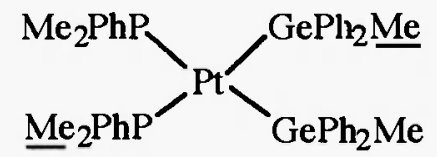

$\delta 0.70 \mathrm{ppm}$

(d with two satellites)

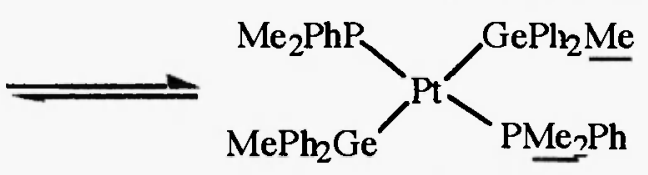

$\delta 1.20 \mathrm{ppm}$

(vt with two satellites)

The isomerization of cis-2 to trans-2 in $\mathrm{C}_{6} \mathrm{D}_{6}$ at various temperatures was followed by observing the change in the two methyl signals of the $\mathrm{PMe} 2 \mathrm{Ph}$ ligands by means of ${ }^{1} \mathrm{H}$ NMR spectroscopy. From the concentrations of the cis and trans isomers af ter equilibria were reached, the following thermodynamic parameters were obtained: $\Delta \mathrm{H}^{\circ}, 6.0 \mathrm{~kJ} \mathrm{~mol}^{1}$ and $\Delta \mathrm{S}^{\circ}, 13.0 \mathrm{~J} \mathrm{~mol}^{-1} \mathrm{~K}^{-1}$.

As a representative example, Fig. 1 shows the molecular structure of $c i s-1$, confirmed by $\mathrm{X}$-ray diffraction analysis.
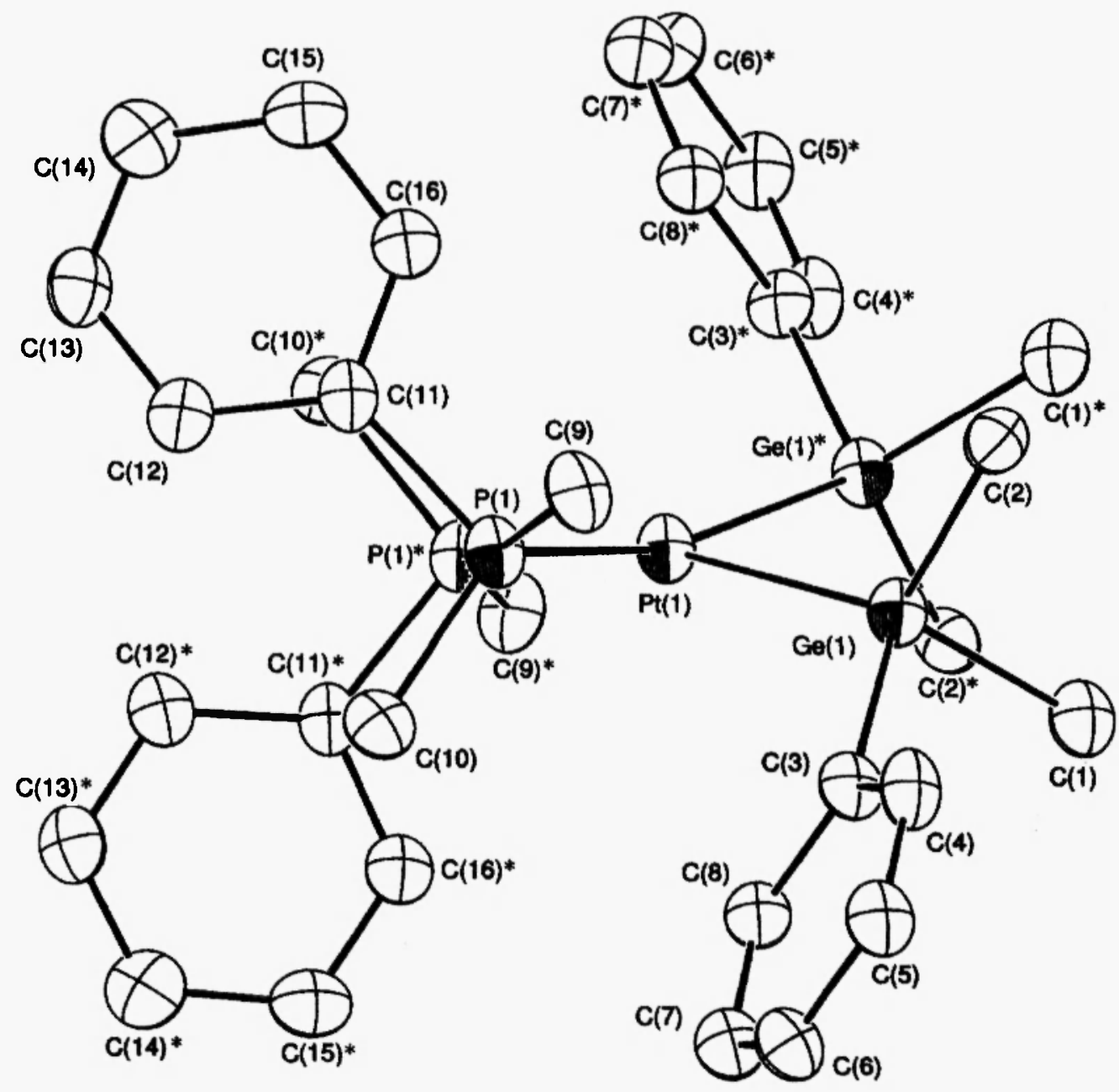

Fig. 1. Molecular structure of the cis-bis(dimethylphenylgermyl)bis(dimethylphenylphosphine)platinum (1). (30\% probability thermal ellipsoids). Hydrogen atoms are omitted for clarity.

Fig. 2 shows the summary of selected bond lengths, bond angles, and dihedral angles in cis-1, cis-2, and trans -3 complexes. 


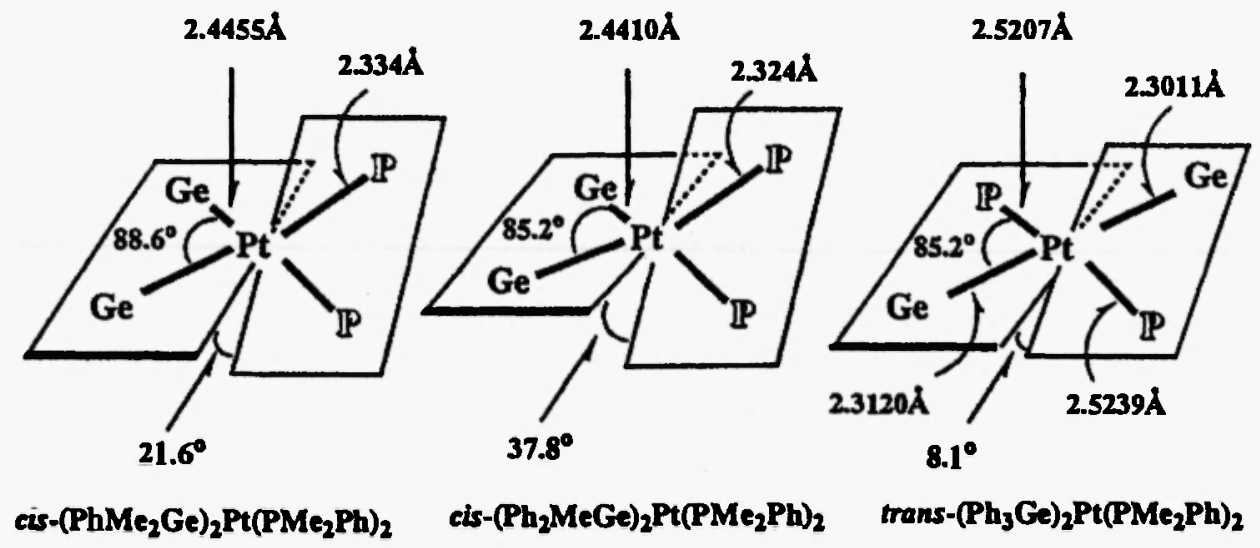

Fig. 2. A summary of selected bond lengths, bond angles, and dihedral angles of $\mathrm{cis}-1$, cis-2, and trans-3.

Both $c t s-1$ and $c i s-2$ have distorted square-planar $c i s$ geometries, with the dihedral angles between the planes composed of $\mathrm{P}(1)-\mathrm{Pt}(1)-\mathrm{P}(2)$ and $\mathrm{Ge}(1)-\mathrm{Pt}(2)-\mathrm{Ge}(2)$ being 21.6 and $37.8^{\circ}$, respectively. The deformation from planarity is considered to be caused by a steric repulsion between the bulky ligands. The two germyl groups are bound to the platinum center in position cis to each other, with the bite angle, $\mathrm{Ge}(1)-\mathrm{Pt}(1)-\mathrm{Ge}(2)$, being $88.6^{\circ}$ for $c i s-1$ and $85.2^{\circ}$ for $c i s-2$. On the other hand, the complex trans-3 has a somewhat distorted squareplanar geometry with a dihedral angles of $8.1^{\circ}$ between the plane composed of $\mathrm{P}(1)-\mathrm{Pt}-\mathrm{Ge}(1)$ and $\mathrm{P}(2)-\mathrm{Pt}$ $\mathrm{Ge}(2)$. The four bond angles of Ge-Pt-P are close to $90^{\circ}$. The bond lengths of Pt-Ge (2.5207(3) and 2.5239 (4) $\AA$ of trans-3 are longer than those of $c t s-1$ and $c i s-2$ (2.4455(9) and 2.4410(7) $\AA$, respectively). On the contrary, the Pt-P lengths of trans-3 (2.3011(9) and 2.3120(9) $\AA$ are shorter than those of cis-1 and cis-2 (2.334(2) and 2.324(1) $\AA$, respectively). These results indicate the greater trans influenece of the germyl ligand than the phopshine ligand.

The thermolysis behavior of these digermylplatinum complexes, 1-3, was examined in sealed NMR tubes. Thermolysis of cis -1 at $80^{\circ} \mathrm{C}$ for $12 \mathrm{~h}$ and cis-2 at $120^{\circ} \mathrm{C}$ for $5 \mathrm{~h}$ led to the formation of digermanes (65 and $60 \%$, respectively) as the major coupling products of the two germyl ligands. Two monogermanes and other unidentified germanium-containing oligomers were produced as by-products.

$$
\begin{aligned}
& \text { cis- }\left(\mathrm{Ph}_{\mathrm{n}} \mathrm{Me}_{3-\mathrm{n}} \mathrm{Ge}\right)_{2} \mathrm{Pt}\left(\mathrm{PMe}{ }_{2} \mathrm{Ph}\right)_{2} \quad \underset{\mathrm{C}_{6} \mathrm{D}_{6} \text { in sealed NMR tube }}{\longrightarrow} \\
& \left(\mathrm{Ph}_{\mathrm{n}} \mathrm{Me}_{3-\mathrm{n}} \mathrm{Ge}\right)_{2}+\mathrm{Ph}_{\mathrm{n}} \mathrm{Me}_{\mathrm{n}+2} \mathrm{Ge}+\mathrm{Ph}_{\mathrm{n}+1} \mathrm{Me}_{\mathrm{n}+1} \mathrm{Ge}+\text { oligomers } \\
& \begin{array}{llll}
\mathrm{n}=1 & 65 \% & 2 \% & 10 \%
\end{array} \\
& \begin{array}{llll}
\mathrm{n}=2 & 60 \% & 12 \% & 0 \%
\end{array}
\end{aligned}
$$

On the other hand, heating of trans -3 at $70{ }^{\circ} \mathrm{C}$ for $24 \mathrm{~h}$ gave tetraphenylgermane $(60 \%)$ as main products. Other unidentified products were also detected.

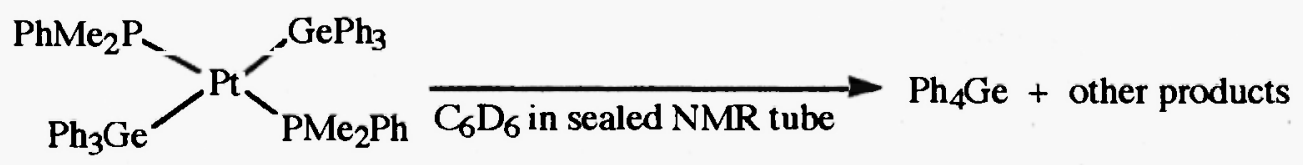


For examining the reactivity of the digermylplatinum complexes that are assumed to be involved in the platinum-catalyzed bis-gernnylation of alkynes, we treated cis-2 with 5.0 equiv. of phenylacetylene at $65^{\circ} \mathrm{C}$ for $24 \mathrm{~h}$. The reaction gave $Z$-1-phenyl-1,2-bis(diphenylmethylgernyl)ethene in $31 \%$ yields.

$$
\text { cis-2 }+\mathrm{PhC} \equiv \mathrm{CH} \underset{60^{\circ} \mathrm{C}, 24 \mathrm{~h}}{\longrightarrow} \mathrm{Ph}_{2} \mathrm{MeGe}^{-} \mathrm{C}=C_{\mathrm{GePh}_{2} \mathrm{Me}}^{\mathrm{Hh}}
$$

Vinyl-germyl type platinum complex is a possible intermediate species in the reactions of digermylplatinum complexes $1-3$ with phenylacetylene in the process to liberate a bis-germylation product of the alkyne. Complex 2 reacted with phenylacetylene ( 2 equiv) at $65^{\circ} \mathrm{C}$ for $1.5 \mathrm{~h}$ in $\mathrm{C}_{6} \mathrm{D}_{6}$ to give regioselectively the corresponding insertion complex 4 in quntitatively yields, as confirmed by NMR spectroscopy.

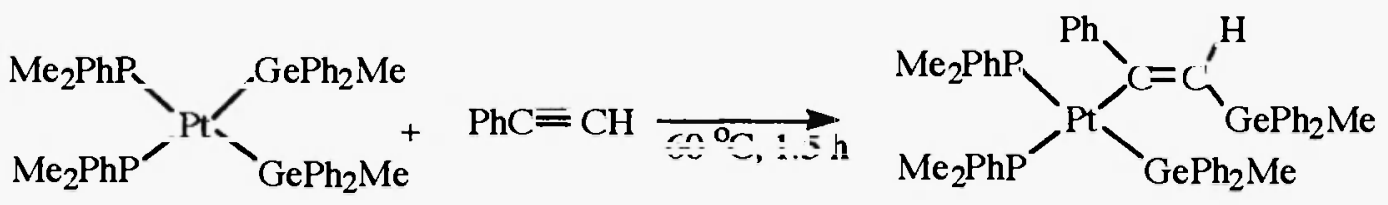

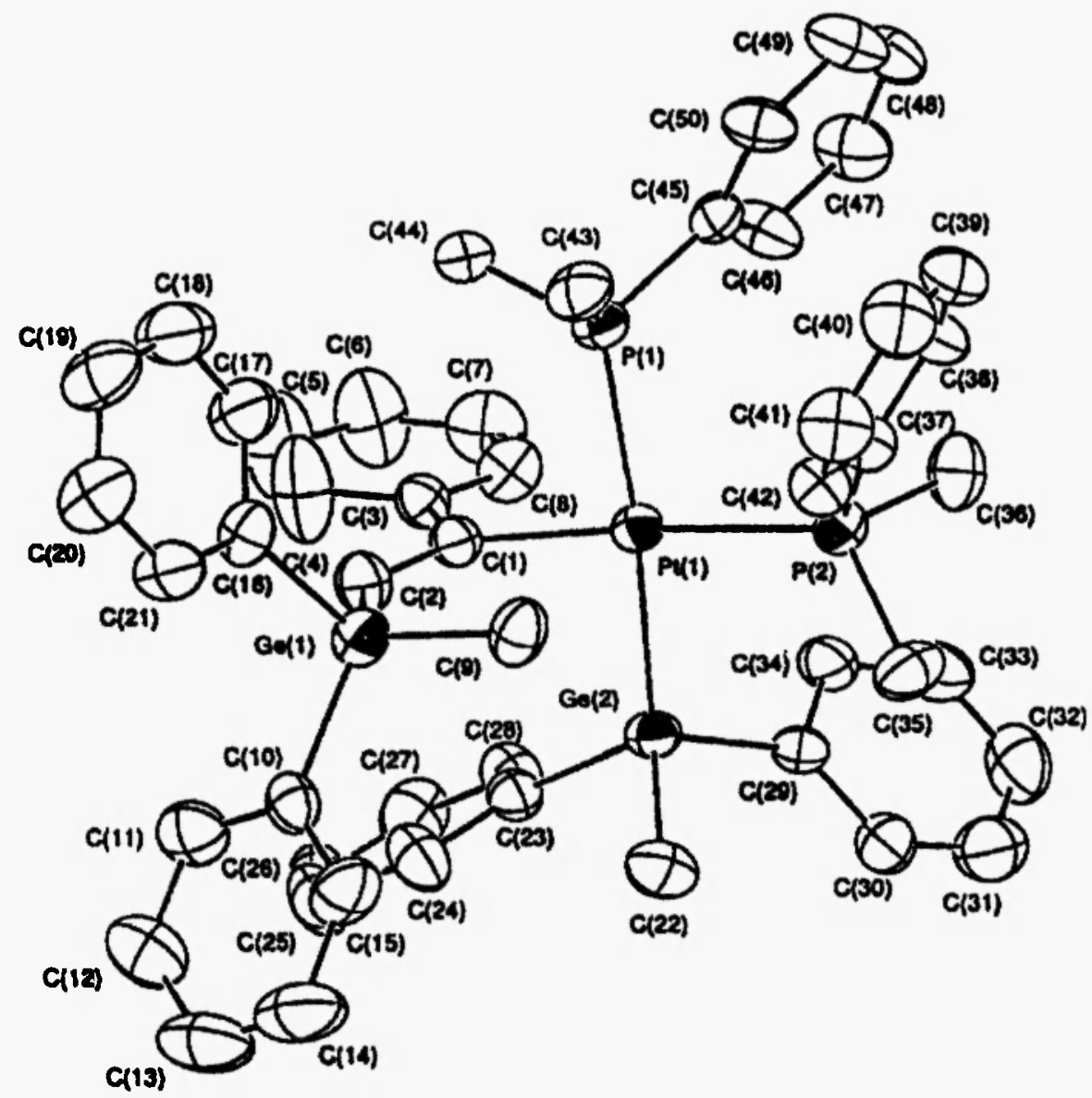

Fig. 3. Molecular structure of the methyldiphenylgermyl(1-phenyl-2-methyldiphenylgermylethylenyl)bis(dimethylphenylphosphine)platinum (4). (30\% probability thermanl ellipsoids). Hydrogen atoms are omitted for clarity. 
Complex 4 was isolated as a yellow solid in $88 \%$ yield and characterized by NMR spectroscopy and X-ray diffraction analysis. The ${ }^{31} \mathrm{P}$ NMR of complex 4 exhibited two sets of doublets $\left({ }^{2} J_{\mathrm{PP}}=18 \mathrm{~Hz}\right)$ at $\delta-15.0$ and -18.7 with ${ }^{1} J_{\mathrm{Pl}-\mathrm{P}}$ values of 1811 and $1819 \mathrm{~Hz}$, respectively.

Figure 3 shows the molecular structure of 4 . The platinum atom in 4 has a square-planar geometry, the sum of the four angles about platinum being $360.2^{\circ}$. The $C(1)-C(2)$ distance $(1.351(13) \AA)$ is in the typical range of a carbon-carbon double bond. The $Z$ arrangement of the platinum and germanium atoms bound to the $\mathrm{C}=\mathrm{C}$ double bond clearly shows the occurrence of the $c$ is insertion of phenylacetylene into one of the two Pt-Ge bonds.

Heating of cis-4 in $\mathrm{C}_{6} \mathrm{D}_{6}$ at $80^{\circ} \mathrm{C}$ for $8 \mathrm{~h}$ led to the decomposition of cis-4 (45\%) with the formation of Z-1-phenyl-1,2-bis(diphenylmethylgermyl)ethene in $40 \%$ yield.

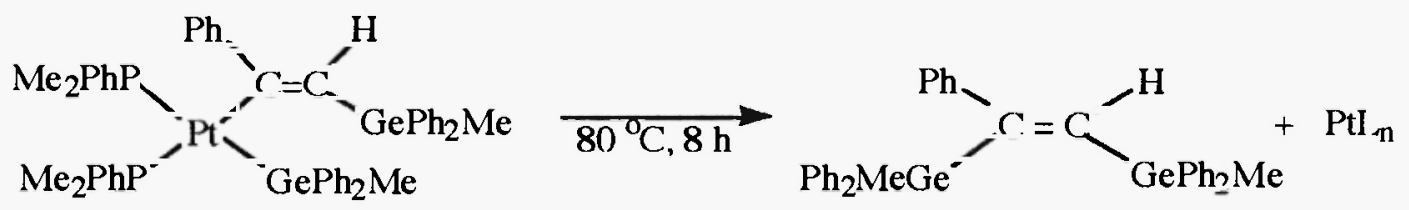

As a mechanism for the bis-germylation of alkynes with a digermane, we propose a catalytic cycle (Schemel) driven by a Pt( 0 ) species generated from a catalyst precursor. The catalytic cycle is composed of (a) the oxidative addition of digermane to the platinum species to form a digermylplatinum intermediate (A), (b) the coordination of an alkyne to $A$ to form an alkyne-coordinated bis-germylation complex (B), (c) the insertion of the coordinated alkyne into one of the Pt-Ge bonds to form the insertion product (C) having the germyl and vinyl ligands, (d) the reductive elimination of the bis-germylation product of alkyne with the regeneration of the active platinum species that further carries the catalytic cycle.

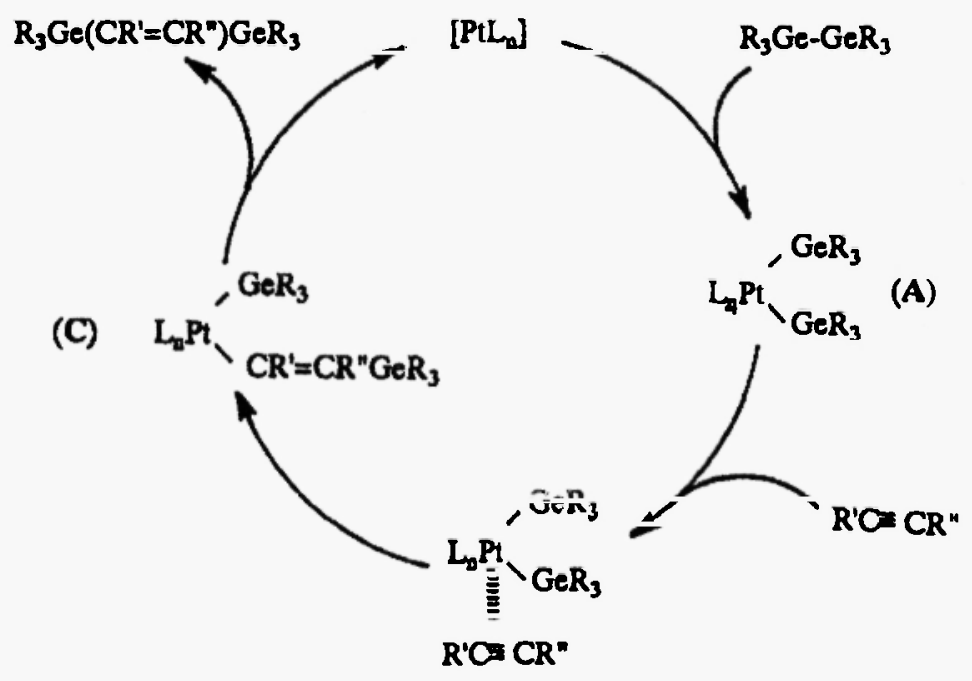

(B)

Scheme 1 .

For obtaining further information we attempted the detection of an intermediate species involved in the process by a NMR examination of the reaction system.

The formation of the bis-germylation product of phenylacetylene upona a treatment of cis-2 with phenylacetylene at $65^{\circ} \mathrm{C}$ lends support to the involvment of the digermylplatinum complex in the catalytic bis-germylation of alkynes, as proposed in Scheme 1. For examining whether the isolated digermylplatinum complex 2 in fact acts as a catalyst for the bis-germylation of phenylacetylene, hexamethyldigermane $\mathrm{Me}_{3} \mathrm{GeGeMe}_{3}$ was treated with phenylacetylene in the presence of 2 at $65^{\circ} \mathrm{C}$ for $24 \mathrm{~h}$. The bis-germylation product of phenylacetylene was obtained in $2 \%$ yield. The low yield may be partly due to an interference 
effect of the phosphine ligand, which was used to stabilized the digermylplatinum complex in the oxidative addition of the digermane to a $\mathrm{Pt}(0)$ species.

The regioselective formation of the germyl(germylvinyl)platinum complex 4 upon the treatment of cis-2 with phenylacetylene supports on the involvment of possible intermediates corresponding $B$ and $\mathbf{C}$ in Scheme 1.

As an alternative route to give $\mathrm{C}$, a process involving a prior coordination of the alkyne to a $\mathrm{Pt}(0)$ species followed by the oxidative addition of a digermane is conceivable. How ever, a phenylacetylene-coodinated triphenylphosphine complex did not react with $\mathrm{MePh}_{2} \mathrm{GePh}_{2} \mathrm{Me}$ or $\mathrm{Me}_{3} \mathrm{GeGeMe}$ upon heating at $60-120^{\circ} \mathrm{C}$ for $16 \mathrm{~h}$, and no bis-germylation product of phenylacetylene was produced.

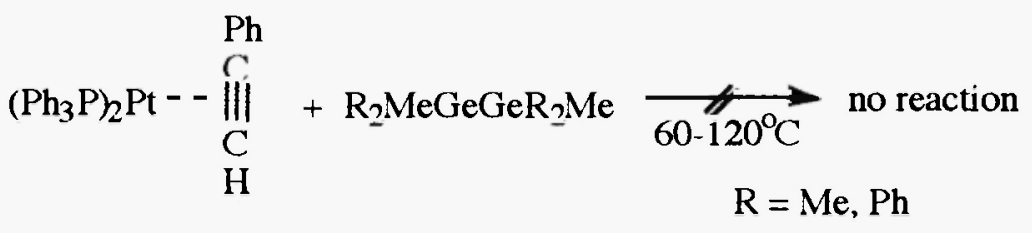

Presumably, the coordination of phenylacetylene to the $\mathrm{Pt}(0)$ complex through a $\pi$ bond makes the platinum complex less electron-rich by back-donation, and renders it less susceptible to an oxidative addition reaction with the digermane.

\section{References and Notes}

1 R. West, in "Comprehensive Organometallic Chemistry," ed by G. Wilkinson, F. G. A Stones, and E. W. Abel, Pergamon Press, New York (1982), Vol. 2, p.376.

2 R. West, in "Comprehensive Organometallic Chemistry," ed by G. Wilkinson, F. G. A Stones, and E W. Abel, Pergamon Press, New York (1995), Vol. 2, p.77.

3 I. Ojima, in "The Chemistry of Organic Silicon Compounds," ed by S. Patai anD Z. Rappoport, John Wiley \& Sons, New York (1989).

4 T. D. Tilley, in "The Silicon-Heteroatom Bond," ed by S. Patai and Z. Rapport, John Wiley \& Sons, Chichester (1991), Chapt. 9.

5 S. Murai and N. Chatani, J. Synth. Org. Chem. Jpn., 51, 421 (1993) and references cited therein.

6 H. Yamashita and M. Tanaka, Bull. Chem. Soc. Jpn., 68, 403 (1995) and references cited therein.

7 M. Suginome, H. Oike, S. -S.Park, and Y. Ito, Bull. Chem. Soc. Jpn., 69, 289 (1996) and references cited therein.

8 M. Suginome and Y. Ito, Chem. Rev., 100, 3221 (2000)

9 T. Tsumuraya and W. Ando, Organometallics, 8, 2286 (1989).

10 T. Hayashi, H. Yamashita, T. Sakakura, and M. Tanaka, Chem. Lett., 1991, 245.

11 K. Mochida, C. Hodota, H. Yamashita, and M. Tanaka, Chem. Lett., 1992, 1635. 